\title{
Transcriptional Regulation of Glucose Sensors in Pancreatic $\beta$-Cells and Liver: An Update
}

\author{
Jin-Sik Bae ${ }^{1,2}$, Tae-Hyun Kim ${ }^{1,2,3}$, Mi-Young Kim ${ }^{1,2}$, Joo-Man Park ${ }^{1,2,3}$ and Yong-Ho Ahn ${ }^{1,2,3, *}$ \\ 1 Department of Biochemistry and Molecular Biology, Yonsei University College of Medicine, \\ Seoul 120-752, Korea; E-Mails: baejinsik@yuhs.ac (J.-S.B.); taehyun@yuhs.ac (T.-H.K.); \\ theresakim@yuhs.ac (M.-Y.K.); jjumans@yuhs.ac (J.-M.P.) \\ 2 Center for Chronic Metabolic Disease Research, Yonsei University College of Medicine, \\ Seoul, Korea \\ 3 Brain Korea 21 Project for Medical Sciences, Yonsei University College of Medicine, Seoul, \\ Korea
}

* Author to whom correspondence should be addressed; E-Mail: yha111@yuhs.ac; Tel.: +82-2-2228-1674; Fax: +82-2-312-5041.

Received: 1 February 2010; in revised form: 7 May 2010 / Accepted: 13 May 2010 / Published: 19 May 2010

\begin{abstract}
Pancreatic $\beta$-cells and the liver play a key role in glucose homeostasis. After a meal or in a state of hyperglycemia, glucose is transported into the $\beta$-cells or hepatocytes where it is metabolized. In the $\beta$-cells, glucose is metabolized to increase the ATP:ADP ratio, resulting in the secretion of insulin stored in the vesicle. In the hepatocytes, glucose is metabolized to $\mathrm{CO}_{2}$, fatty acids or stored as glycogen. In these cells, solute carrier family 2 (SLC2A2) and glucokinase play a key role in sensing and uptaking glucose. Dysfunction of these proteins results in the hyperglycemia which is one of the characteristics of type 2 diabetes mellitus (T2DM). Thus, studies on the molecular mechanisms of their transcriptional regulations are important in understanding pathogenesis and combating T2DM. In this paper, we will review a recent update on the progress of gene regulation of glucose sensors in the liver and $\beta$-cells.
\end{abstract}

Keywords: glucose sensor; solute carrier family 2 (SLC2A2); glucokinase (GCK); transcription; liver; pancreatic $\beta$-cell 


\section{Introduction}

Glucose is one of the most important molecules that acts as a basic fuel for energy source and a substrate for intermediary metabolism as well. Because of its essential role in the metabolism, most cells have evolved to have an apparatus to sense and transport extracellular glucose into the cells. The glucose sensing in mammalian cells is regulated by both direct and indirect pathways. In the postprandial state, temporarily increased glucose has to be disposed of to prevent the cells from gluco-toxicity. After meal, glucose in the blood is absorbed near the portal vein, and metabolized in the liver and pancreas [1].

Blood glucose is transported into the liver and $\beta$-cells of pancreas through solute carrier family 2 (SLC2A2, also known as GLUT2) and immediately phosphorylated by glucokinase present in the liver (LGCK) or $\beta$-cells ( $\beta$ GCK) which acts as a glucose sensor. Glucose-6-phosphate in the hepatocytes undergoes glycolysis, glycogenesis, pentose phosphate pathway, or hexosamine biosynthetic pathway depending on the metabolic needs. Both SLC2A2 and GCK have high $K_{\mathrm{m}}$ values and high capacity and thus are able to sense and transport glucose into hepatocytes or $\beta$-cells in proportion to the blood glucose level [2].

In the $\beta$-cells, glucose is metabolized and thereby increases intracellular the ATP:ADP ratio which causes suppression of ATP-sensitive $\mathrm{K}^{+}$channel and triggers insulin secretion [3-5]. In addition, the gene expression of insulin is stimulated by glucose and is subjected to control at the transcriptional level.

Most of the type 2 diabetes mellitus (T2DM)-associated genes are mainly involved both in $\beta$-cell function and peripheral insulin sensitivity. Mutations in the $G C K$ gene are associated with maturity onset diabetes of the young (MODY), a subtype of diabetes characterized by monogenic autosomal dominant transmission, early age of onset (typically less than 25 years of age) and primary defects in $\beta$-cell function. MODY are also associated with mutations in the genes encoding transcription factors like, hepatic nuclear factor 4 alpha $(H N F 4 A)$, HNF1 homeobox A (HNF1A), pancreatic and duodenal homeobox 1 (PDX1), HNF1 homeobox $\mathrm{B} \quad(H N F 1 B)$ and neurogenic differentiation 1 (NEUROD1) [6-8]. Furthermore, these transcription factors are known to be involved in the regulation of tissue-specific expression of $S L C 2 A 2$ and/or $G C K$ genes [9]. Dysfunctional mutation in SLC2A2 gene is also found in one patient with T2DM [10].

The gene expression of $S L C 2 A 2$ and $G C K$ is affected by metabolic conditions and are also tissue-specific. SLC2A2 is primarily expressed in the liver and $\beta$-cells [11,12] and its gene expression is affected by the blood glucose and insulin $[13,14]$. In diabetic animal models, SLC2A2 mRNA level is increased in the liver [15], whereas it is decreased in $\beta$-cells [16,17]. GCK is expressed mainly in the mammalian liver and $\beta$-cells, with two alternative promoters that govern tissue-specific expression [18-21]. The $\beta G C K$ promoter (upstream promoter) is regulated by glucose, whereas the LGCK promoter (downstream promoter) is regulated by insulin and glucagon [21].

In this review, we will focus on an update on the transcriptional regulation of SLC2A2 and GCK genes in the liver and $\beta$-cells. Studying the molecular mechanisms in relation to T2DM will help understand its pathogenesis and find potential drug targets for the development of therapeutic drugs. 


\section{Transcriptional Regulation of $S L C 2 A 2$ in the Liver and $\beta$-Cells of Pancreas}

Since the cloning of the promoter regions of $S L C 2 A 2$ gene, numerous studies on the transcriptional regulation have been performed (for a review see [9]). Unlike those of human or mouse $S L C 2 A 2$ genes, rat Slc2a2 promoter contains three noncoding exons (exons 1A, 1B, and 1C; Figure 1) [22]. As shown, several HNFs are involved in transcriptional regulation of $S L C 2 A 2$ genes.

Figure 1. Schematics of transcriptional regulatory elements on the $S L C 2 A 2$ gene promoter.

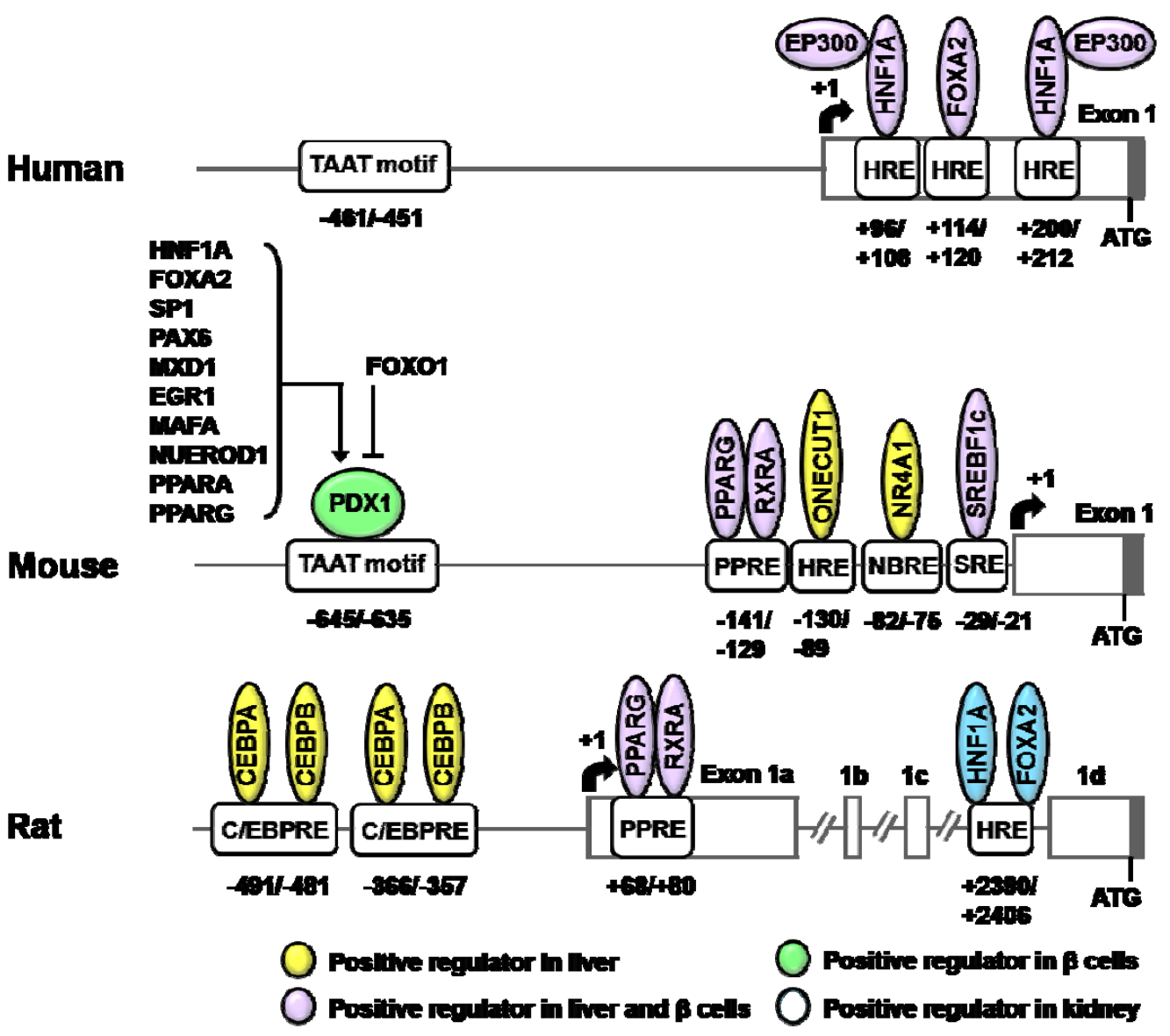

Abbreviations: HNF1A, HNF1 homeobox A; EP300, E1A binding protein p300; FOXA2, forkhead box A2 (also known as HNF3B); PDX1, pancreatic and duodenal homeobox 1; SP1, Sp1 transcription factor; PAX6, paired box 6; MXD1, MAX dimerization protein 1; EGR1, early growth response 1; MAFA, v-maf musculoaponeurotic fibrosarcoma oncogene homolog A; NEUROD1, neurogenic differentiation 1; PPARA, peroxisome proliferator-activated receptor alpha; PPARG, peroxisome proliferator-activated receptor gamma; FOXO1, forkhead box O1; RXRA, retinoic X receptor alpha; ONECUT1, one cut homeobox 1 (also known as HNF6); NR4A1, nuclear receptor subfamily 4, group A, member 1; SREBF1c, sterol regulatory element binding transcription factor 1c; CEBPA, CCAAT/enhancer binding protein $(\mathrm{C} / \mathrm{EBP})$ alpha; CEBPB, CCAAT/enhancer binding protein $(\mathrm{C} / \mathrm{EBP})$ beta; HRE, HNF response element; PPRE, PPAR response element; NBRE, nerve growth factor I-B response element; SRE, SREBF response element; C/EBPRE, CEBP response element. +1 , transcription start site. 
HNF1A is an essential transcription factor for the expression of Slc2a2 gene in $\beta$-cells. In transgenic mice over-expressing a dominant negative form of HNF1A, the expression of Slc2a2 gene is decreased in the pancreatic islets. In Hnfla knockout mice, the expression of Slc2a2 gene was decreased in the pancreatic islets, but not affected in the liver [23-25].

Both HNF1A and forkhead box A2 (FOXA2, also known as HNF3B) are responsible for the tissue-specific expression of the human $S L C 2 A 2$ gene. These factors synergistically increase the promoter activity of human SLC2A2 gene in NIH-3T3 cells. Binding of HNF1A and FOXA2 to $+96 /+108$ and $+114 /+120$ bp region of human $S L C 2 A 2$ promoter was identified and these binding sites were well conserved in the mouse and rat gene [26]. HNF1A and FOXA2 also upregulate Slc2a2 mRNA in the kidney of diabetic rats [27]. Another HNF1A binding site $(+200 /+212 \mathrm{bp})$ was found in the promoter of human $S L C 2 A 2$ gene. A mutation study revealed that the $+200 /+212$ bp site is more important than the $+96 /+108$ bp one in HNF1A-induced SLC2A2 gene expression. Moreover, E1A binding protein p300 (EP300) potentiates activity of the human $S L C 2 A 2$ promoter by interacting with the transactivation domain of HNF1A [28].

In transgenic mice or adenoviral transduction of recombinant Foxa2 (AdFoxa2), Slc2a2 mRNA level was decreased in the liver [29, 30], presumably because FOXA2 represses one cut homeobox 1 (Onecut1, also known as Hnfo) gene expression, which is a positive regulator of Slc2a2 gene in the mouse liver [31]. However, mRNA levels of Slc2a2 and Onecut1 were not altered in liver specific Foxa2 knockout mice [32]. In addition, Slc2a2 gene expression was not altered in $\beta$-cell specific Foxa2 knockout mice [33]. These reports suggest that transactivating effect of FOXA2 on Slc2a2 promoter may be weak or absent in mouse liver and $\beta$-cells.

FOXA3 (also known as HNF3G) is known to act as a positive regulator of the Slc2a2 gene in the liver, although upregulation of the gene was not observed in $\beta$-cells [34]. HNF4A is also known to activate $S L C 2 A 2$ gene expression in embryonic stem cells [35] and $\beta$-cells [36].

PDX1 plays a key role in the development of pancreas by orchestrating gene regulation in $\beta$-cells [37] and is known to upregulate Slc2a2 gene expression through TAAT motif in the Slc2a2 promoter [38]. Slc2a2 gene expression in the $\beta$-cell specific $P d x 1$ knockout $[39,40]$ and $P d x 1$ heterozygote mice [41] is dramatically reduced when compared to that of wild type mice.

Although PDX1 was shown to bind in vitro to the promoter region of $\beta$-cell specific genes, including Slc2a2 (EMSA data), chromatin immunoprecipitation (ChIP) assays indicated that PDX1 did not bind to the promoter of Slc2a2 gene in the $\beta$-TC3 cells. These results suggest that selectivity of PDX1 may depend on the cell type specific chromatin structures and/or the presence of interacting proteins [42]. Indeed, PDX1 of which binding to Slc2a2 promoter is reinforced by high-mobility group N 3 (HMGN3), a chromatin binding protein that is highly expressed in $\beta$-cells [43].

Since various transcription factors, like HNF1A, FOXA2, Sp1 transcription factor (SP1) [44], paired box 6 (PAX6) [45], MAX dimerization protein 1 (MXD1) [46], early growth response-1 (EGR1) [47,48], v-maf musculoaponeurotic fibrosarcoma oncogene homolog A (MAFA) [49], neurogenic differentiation 1 (NEUROD1) [50], peroxisome proliferator-activated receptor alpha (PPARA) [51] and peroxisome proliferator-activated receptor gamma (PPARG) [52], were known to be positive-regulators of $P D X 1$ gene, it was speculated that many of these transcription factors may indirectly affect gene expression of $S L C 2 A 2$ through PDX1. Slc2a2 mRNA level was decreased in INS832/13 cells in which forkhead transcription factor FOXO1 is overexpressed [53]. Since FOXO1 
binds to the PDX1 promoter and inhibits FOXA2-induced PDX1 expression, the effect of FOXO1-suppression of Slc2a2 gene expression might occur in an indirect way [54].

$\mathrm{V}$-maf musculoaponeurotic fibrosarcoma oncogene homolog B (MAFB) is a critical transcription factor for $\beta$-cell differentiation, although its expression was not observed in adult pancreas $\beta$-cells [55-57]. Slc2a2 and $P d x 1$ gene expression is reduced in the embryonic pancreas of $M a f b$ knockout mice and MAFB binds to the promoter of Slc2a2 gene in vivo [57]. Because PDX1 is a positive regulator of $S l c 2 a 2$ gene expression, $S l c 2 a 2$ gene expression may be regulated by MAFB either directly or indirectly. Furthermore, Slc2a2 expression is decreased in Mafa-deficient mice [58]. However, MAF response element(s) in the Slc2a 2 promoter has not been identified.

PPARG directly activates $S L C 2 A 2$ gene expression in the liver and $\beta$-cells [59-61]. Rosiglitazone increased SLC2A2 mRNA level in the primary cultured hepatocytes, Alexander [59] and INS-1 cells [62]. Troglitazone also increased Slc2a2 mRNA level in primary cultured islets from rats [52,60]. In addition, decreased Slc $2 a 2$ gene expression in the islets of $d b / d b$ mouse was restored by pioglitazone treatment $[63,64]$. RNAi-suppression of Pparg in INS-1 cells caused reduction in Slc2a2 mRNA levels [52]. The functional PPAR response elements (PPREs) have been identified in the promoters of rat [60] and mouse [59] Slc2a2 gene. Therefore, thiazolidinediones (TZDs) may contribute to the transport glucose into the liver or $\beta$-cell by upregulating SLC2A2 gene [61]. PPARA also upregulates the Slc2a2 gene expression in the $\beta$-cells [51,65]. Ppara null mice showed low level of Slc2a2 mRNA in the pancreas [66].

Glucose increased the Slc2a2 gene expression in the liver and $\beta$-cells, both in vivo and in vitro [14,67-70]. Recently, we have identified a sterol regulatory element binding transcription factor 1 (SREBF1) response element (SRE) in the promoter of mouse Slc2a2 gene, which is responsive to glucose in primary cultured hepatocytes [69]. Furthermore, glucose-induction of the Slc2a2 gene expression in pancreatic islets was not found in Srebfl knockout mice [70].

Also, cyclic adenosine monophosphate (cAMP) prevents the glucose-mediated stimulation of Slc2a2 gene expression in hepatocytes. The $-312 /+49$ bp region of the mouse Slc $2 a 2$ promoter is responsible for cAMP responsiveness [71]. However, functional cAMP response element(s) within this region has not been identified.

An orphan nuclear receptor NR4A1 (nuclear receptor subfamily 4, group A, member 1) binds to nerve growth factor I-B response element (NBRE) in mouse Slc2a2 promoter $(-82 /-75 \mathrm{bp})$ and increases mRNA level in primary cultured hepatocytes and liver. Furthermore, Slc2a2 mRNA induced by NR4A1 is synergistically enhanced by PPARG coactivator 1 alpha (PPARGC1A) [72]. Because NR4A1 expression is highly regulated by the cAMP axis in the liver [72], these results are not consistent with the previous report that cAMP decreases the promoter activity of the Slc2a2 gene [71]. Further studies are needed to elucidate these contradictory results.

Insulin plays a negative role in Slc2a2 gene expression in the liver [14]. Since insulin-FOXO1 pathway is responsible for the negative role in insulin-mediated gene expression [73], it is tempting to speculate that FOXO1 may be a negative regulator of $S l c 2 a 2$ gene expression. However, there is no evidence that FOXO1 is involved in the gene expression of Slc $2 a 2$ in the liver, although its negative role of FOXO1 in the Slc2a2 gene expression was shown in $\beta$-cells. 
CCAAT/enhancer binding protein (CEBP) is shown to activate rat Slc2a2 promoter in HepG2 cells. The promoter has two CEBP consensus sequences binding CEBPA and CEBPB (Figure 1). These factors synergistically activate the promoter [74].

Kruppel-like factor 7 (KLF7) is known to reduce mRNA level of SLC2A2 in HIT-T15 and HepG2 cells. Because KLF7 is shown to reduce $P D X 1$ gene expression in HIT-T15 cells [75], SLC2A2 gene expression may be regulated by KLF7 either directly or indirectly.

Although tissue-specific transcriptional regulation is not absolutely consistent between human and mouse [76], SLC2A2 gene expression in liver was activated by ONECUT1, FOXA3, PPARG, SREBF1c, NR4A1, CEBPA, CEBPB and KLF7. On the other hand, SLC2A2 gene expression in $\beta$-cells was activated by HNF1A, HNF4A, PDX1, HMGN3, MAFA, MAFB, PPARA, PPARG and KLF7 and was suppressed by FOXO1. The gene expression or activity of these regulators in abnormal conditions like high-fat or high-carbohydrate diet and cellular stress may contribute to the etiology of T2DM.

\section{Transcriptional Regulation of Glucokinase (GCK)}

\subsection{Beta Cell Glucokinase ( $\beta G C K)$}

GCK plays a critical role in maintaining the postprandial glucose level near $5 \mathrm{mM}$, which is achieved by glucose stimulated insulin secretion (GSIS) from $\beta$-cells and glucose metabolism in the liver [77]. $\beta$ GCK is a primary determinant of blood glucose level because it senses glucose for GSIS.

Upregulation of $\beta G c k$ gene expression by glucose is mediated by insulin. In this mechanism, insulin receptor B type, PI3K class 1a and p70 s6 kinase pathway are known to be involved in glucose-regulated $\beta G c k$ transcription [78]. Furthermore, $\beta G c k$ gene expression is increased when MIN6 cells were cultured at $30 \mathrm{mM}$ glucose [79]. However, $\beta G c k$ mRNA level is not changed in rats which are subjected to fasting/refeeding although LGck gene expression is significantly increased [80]. Indeed, the $4 \mathrm{~kb}$ promoter reporter construct of the $\beta G c k$ gene was not activated either by glucose (30 $\mathrm{mM})$ or insulin $(20 \mathrm{nM})$ [81]. These studies indicate that the role of glucose or insulin in the activation of $\beta \mathrm{GCK}$ may occur by stabilization rather than upregulation of $\beta G c k$ gene expression in insulinoma cells [21].

As shown in Figure 2, the gene expression of $\beta G C K$ is regulated by various transcription factors. In its 5'-flanking region, there are three upstream promoter elements (UPEs) and two Pal motifs. Particulary, UPE-3 and Pal motifs are well conserved in the rat, mouse and human genes $[19,82,83]$. The Pal motifs consist of inverted repeats separated by $1 \mathrm{bp}$ (TGGTCACCA). The promoter activity of $\beta G c k$ gene was decreased by the introduction of mutation in the Pal motifs. These Pal motifs are pivotal determinants for the neural/neuroendocrine cell-specific expression of the Gck promoter $[82,83]$.

UPEs have AT-rich sequence, which is known to be responsible for PDX1 activation. PDX1 is a master regulator for maintaining function and differentiation of $\beta$-cell. In the presence of glucose, PDX1 is phosphorylated and translocated into nucleus [84-86]. Expression of PDX1 increased the reporter activity of $\beta G c k$ promoter in CHO cells. PDX1 binding site is conserved at UPE3 region in human $\beta G C K$ promoter and may play an essential role for $\beta$-cell function [87]. However, $\beta$-cell 
specific disruption of $P d x 1$ did not affect the expression of $\beta G c k$ although Slc2a2 expression was down-regulated [39]. The transcriptional role of PDX1 on the $\beta G C K$ gene is not fully understood.

A basic helix-loop-helix (bHLH) transcription factor, NEUROD1 is known to bind $\beta G c k$ promoter ( $-221 /-216$ bp; E-box) with E47 as a heterodimeric partner and transactivates the $\beta G c k$ gene [88]. In addition, nuclear receptor subfamily 0 , group B, member 2 (NR0B2, also known as SHP) interacts with NEUROD1 and represses the transcriptional activity of NEUROD1 by competing with coactivator EP300 [89]

PPARG/RXRA (retinoic X receptor alpha) binds to the promoter of rat $\beta G c k$ gene of which binding element (PPRE) is located at $+47 /+68$ bp. In addition, troglitazone increased the endogenous expression and enzyme activity of $\beta$ GCK [24]. Knockdown of Pparg using siRNA resulted in a decrease in the mRNA level of $P d x 1, G c k$, Slc2a2 and insulin II [52].

Figure 2. Schematics of transcriptional regulatory elements on the $\beta G C K$ gene promoter.

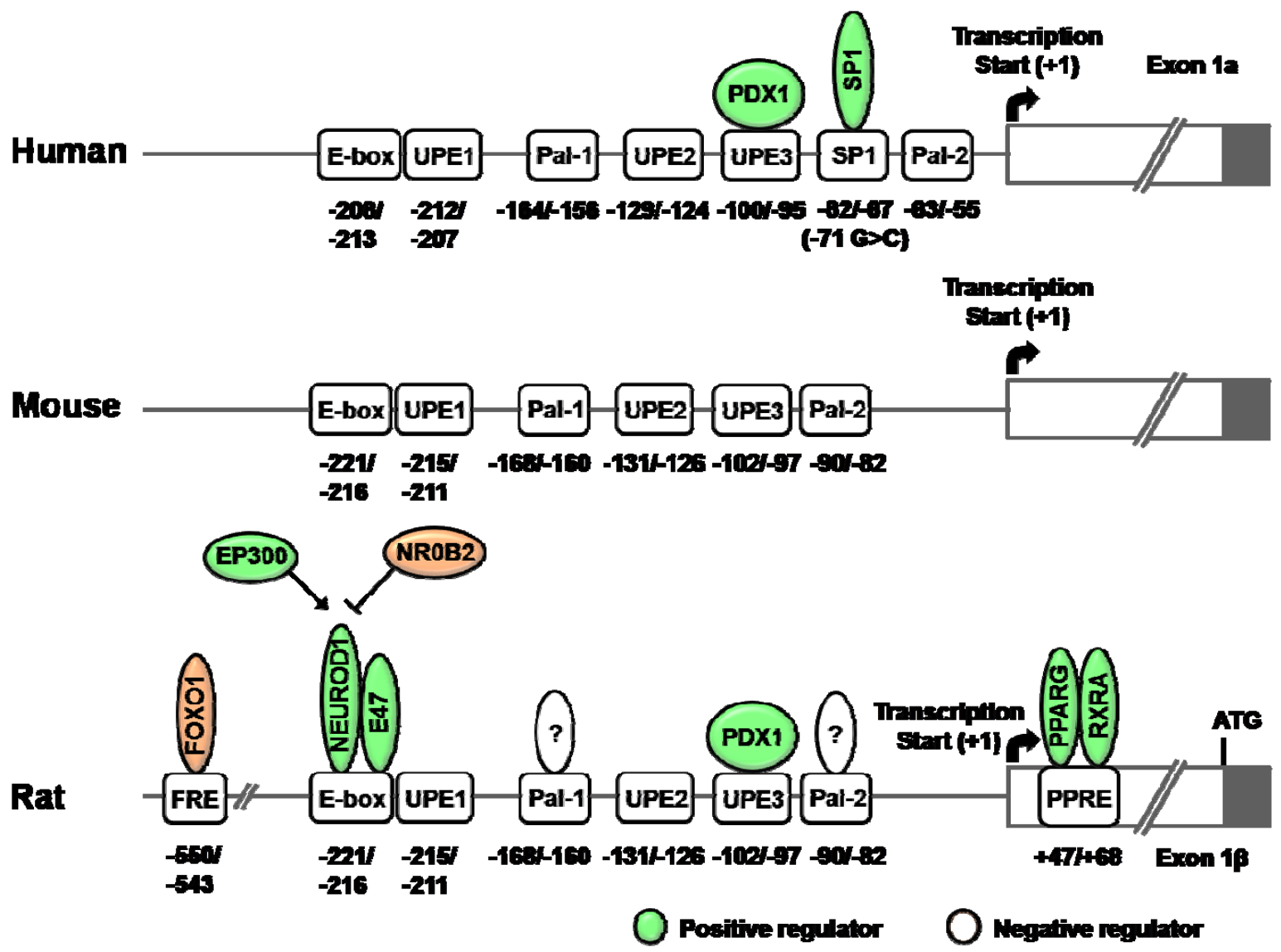

Abbreviations: PDX1, pancreatic and duodenal homeobox 1; SP1, Sp1 transcription factor; FOXO1, forkhead box O1; NEUROD1, neurogenic differentiation 1; E47, an immunoglobulin enhancer-binding factor; EP300, E1A binding protein p300; NR0B2, nuclear receptor subfamily 0, group B, member 2 (also known as SHP); PPARG, peroxisome proliferator-activated receptor gamma; RXRA, retinoic $\mathrm{X}$ receptor alpha; UPE, upstream promoter element; FRE, FOXO1 response element; PPRE, PPAR response element. 
In addition, insulin-like growth factor 1 (IGF1) is known to induce $\beta G c k$ gene expression by phosphorylating FOXO1. FOXO1 response element (FRE) is located at $-550 /-543$ bp of rat $\beta G c k$ promoter and FOXO1 binding to FRE is decreased by IGF1 in vitro [90].

Although PDX1, NEUROD1 and NK2 homeobox 2 (NKX2-2) bind to the region of $-285 /-5$ bp in the mouse $\beta G c k$ promoter, their respective response elements in the $\beta G c k$ promoter have not been characterized [91]. Consistent with a role of NKX2-2 on the $\beta G c k$ promoter, $N k x 2-2$ knockout mice revealed a reduction in the $\beta G c k$ mRNA level. In addition, NKX2-2 appeared to play an important role for the differentiation of $\beta$-cells [92].

\subsection{Liver Glucokinase (LGCK)}

The gene expression of LGck is decreased in streptozotocin-induced diabetic rats and restored by insulin administration [93]. In addition, LGck gene expression is increased by insulin and decreased by the glucagons-cAMP system in primary cultured hepatocytes [94]. Insulin-induction of LGck gene expression is shown to be blocked by LY294002 or wortmannin, a PI3K inhibitor [95]. Furthermore, LGck gene expression is inhibited by a dominant negative form of insulin receptor substrate 1 (IRS1) [96]. These studies support that insulin is a principal regulator of LGck gene expression.

SREBF1c, one of the master regulators of lipogenesis, is dramatically induced by insulin [97,98]. Administration of recombinant adenovirus of Srebflc to streptozotocin-induced diabetic mice restored LGck and lipogenic enzymes normalizing blood glucose level despite that insulin is absent [99]. In addition, adenoviral expression of dominant negative form of SREBF1c in primary cultured hepatocytes decreased insulin-induction of LGck gene, suggesting a direct participation of SREBF1c in the LGck gene expression [100]. Furthermore, direct binding site of SREBF1c on rat LGck promoter is identified [101]. However, LGck gene expression is still increased by refeeding the Srebflc knockout mice [102]. Moreover, LGck gene expression is not changed even though Srebflc was knockdown by siRNA although fatty acid synthase mRNA level is decreased. These studies suggest that SREBF1c is not likely to be a mediator of LGck gene expression [103, 104]. Further studies are needed to answer these contradictory results.

HNF4A is known to be an important transcription factor for glucose and lipid homeostasis [35,105]. HNF4A increases the LGCK gene expression and its binding site HRE (HNF response element) is identified in human [106] and rat [107]. During the fasting period, LGCK transcription by HNFA is repressed by FOXO1 which acts as a corepressor, whereas the suppression is restored by feeding where FOXO1 is phosphorylated and extruded to cytosol by insulin [106].

Hypoxia inducible factor 1 alpha subunit (HIF1A) also affects promoter activity of rat LGck gene. HIF1A binding site is localized at $-87 /-80 \mathrm{bp}$ region of the promoter. Both insulin [108] and hypoxia [21,109,110] upregulate LGck gene expression by increasing HIF1A level and its DNA-binding activity. Transactivation by HIF1A was also enhanced by co-expression of HNF4A and EP300. Moreover, HIF1A interacts with HNF4A and each of these factors also interacts with EP300. It was suggested that synergy and cooperative interactions between HIF1A, HNF4A and EP300 might be necessary for insulin-stimulated LGck expression [109].

Signal transducer and activator of transcription 5B (STAT5B) is known to be regulated by insulin [111,112]. STAT5B phosphorylated by insulin is translocated to the nucleus and increases its 
binding to the cis-acting elements, thereby increasing the transcription of target genes. Activated STAT5B by insulin increased LGCK gene expression [113,114]. In humans, the binding site of STAT5B is characterized at $-1368 /-1360$ bp region, but the mouse STAT5 response element (STAT5RE) was unknown. The binding affinity of STAT5B to the human LGCK promoter is also increased by insulin and the activation by insulin occurs in a janus kinase (JAK)-independent manner. Thus, it is suggested that STAT5B plays an important role in the insulin-mediated upregulation of LGck gene [113]. However, insulin is known to increase the transcription of LGck in primary cultured hepatocytes although the tyrosine phosphorylation of STAT5 was not detectable [114].

Figure 3. Schematics of transcriptional regulatory elements on the LGCK gene promoter.

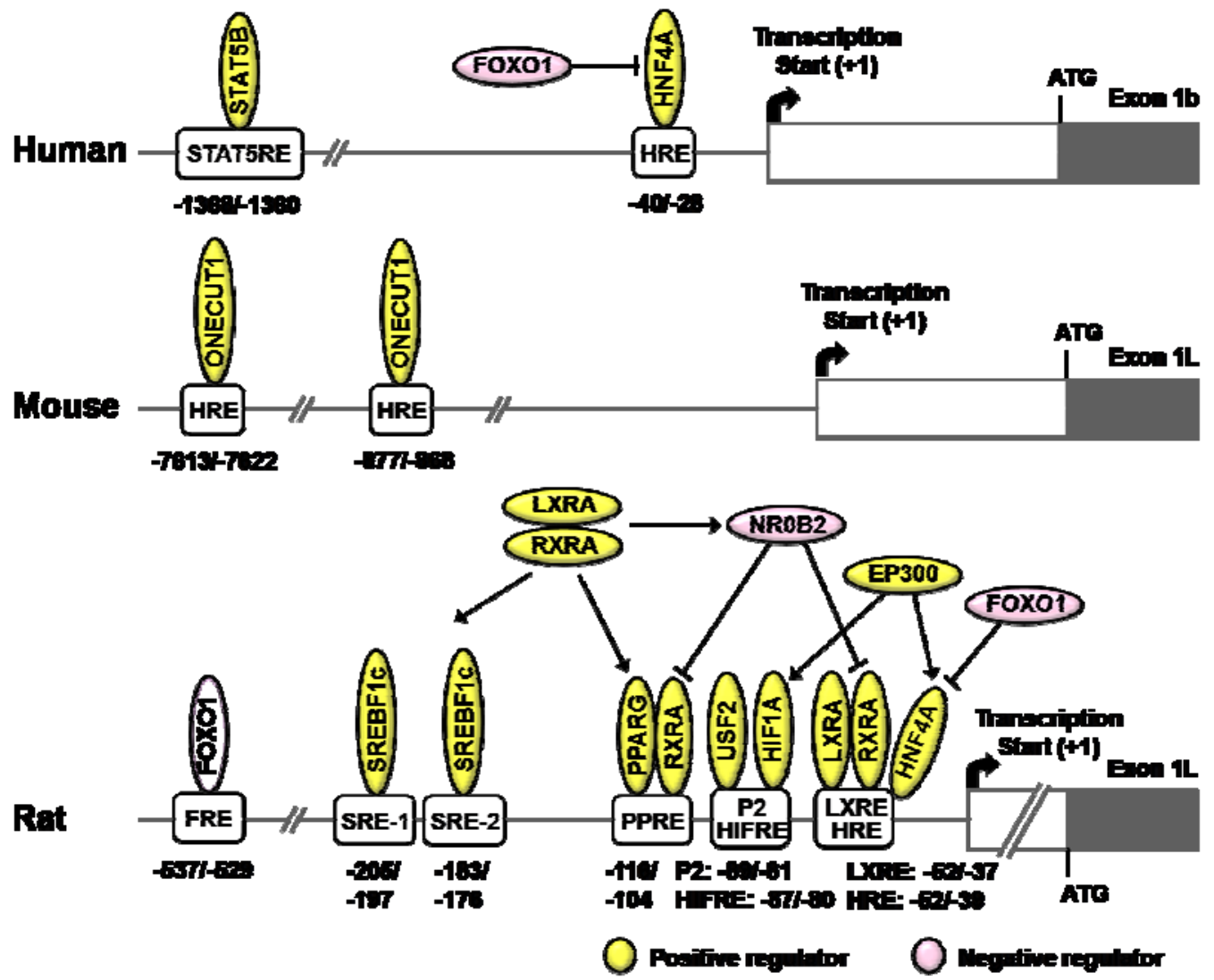

Abbreviations: STAT5B, signal transducer and activator of transcription 5B; HNF4A, hepatic nuclear factor 4 alpha; FOXO1, forkhead box O1; ONECUT1, one cut homeobox 1 (also known as HNF6); SREBF1c, sterol regulatory element binding transcription factor 1c; LXRA, liver X receptor alpha (also known as NR1H3); RXRA, retinoid X receptor alpha; NR0B2, nuclear receptor subfamily 0, group B, member 2 (also known as SHP); EP300, E1A binding protein p300; PPARG, peroxisome proliferator-activated receptor gamma; USF2, upstream stimulatory factor 2; HIF1A, hypoxia induced factor 1 alpha subunit; STAT5RE, STAT5B response element; HRE, HNF response element; FRE, FOXO1 response element; SRE, SREBF response element; PPRE, PPAR response element; HIFRE, HIF1A response element; LXRE, LXR response element.

During the fasting period, sirtuin 1 (SIRT1), an $\mathrm{NAD}^{+}$-dependent deacetylase, decreases the rat LGck gene expression by deacetylating FOXO1, which results in an increase in binding of FOXO1 to 
FRE (-537/-529 bp) of its promoter. They also observed that resveratrol enhances interaction of between FOXO1 and HNF4A, causing a decrease in the binding affinity of HNF4A to the HRE [115].

Upstream stimulating factor 2 (USF2) is responsible for the regulation of LGck gene expression by binding to the $\mathrm{P} 2$ element $(-89 /-81 \mathrm{bp})$, and thus, the transcription factor may be in part responsible for the glucose homeostasis [116].

TZDs are anti-diabetic drugs improving glucose utilization and insulin sensitivity. Troglitazone is a synthetic ligand of PPARG and is shown to upregulate LGck gene expression. The PPRE is located at the $-116 /-104$ bp of LGck gene promoter [117].

Recently, liver X receptor alpha (LXRA, also known as NR1H3) was shown to upregulate LGck gene expression by binding to the LXR response element (LXRE) (-52/-39 bp) in its promoter. In addition, LXRA increases LGck gene expression by inducing SREBF1c and increasing transcriptional activity of PPARG. Furthermore, NR0B2 induced by LXRA plays a role in the fine-tuning the LGck gene expression [118]. Because the binding site of LXRA and HNF4A seems to be overlapped [107], detailed studies are needed to elaborate their precise roles of these factors with regard to specific metabolic conditions.

In mice, ONECUT1 binding site in the LGck gene promoter is localized at $-7613 /-7622$ bp and $-877 /-868$ bp, suggesting a possible link between Onecut1 deficiency and development of T2DM. This study could explain why T2DM occurs in Onecut1 knockout mice [119,120].

\section{Effect of Promoter Polymorphisms on SLC2A2 and GCK Transcription}

Single nucleotide polymorphisms (SNPs) in the promoter regions can affect the binding of transcription factors regulating the transcription of genes. Some significant promoter SNPs of SLC2A2 and $G C K$ genes were reported in T2DM patients.

\subsection{Promoter Polymorphisms in SLC2A2 Gene}

Three common SNPs, $-149 \mathrm{C}>\mathrm{A}$ (rs5393), -122T > C (rs5394) and -44G > A (rs5396), in SLC2A2 promoter were identified in a Danish population. These SNPs were not significantly different in the genotype frequency between T2DM patients and control subjects. In addition, clinical characteristics of T2DM were not significantly associated [121]. However, SNPs rs5393 and rs5394 of SLC2A2 could be high risk genotypes to predict the conversion of T2DM in an obese Finnish subject who had impaired glucose tolerance [122]. This discrepancy is not explained at present, but it may be due to differences in the ethnic group or study population. Detailed functional studies of the effects of promoter SNPs on $S L C 2 A 2$ transcription are needed. 


\subsection{Promoter Polymorphisms in GCK Gene}

Recently, a functional $\beta G C K$ promoter mutation $(-71 \mathrm{G}>\mathrm{C}$ ) was identified in Slovakian and British patients with GCK-MODY phenotype who have no abnormality of the $G C K$ coding seqeuence. The mutation was associated with increased fasting plasma glucose (FPG) levels. In addition, the $\beta G C K$ promoter of the $-71 \mathrm{C}$ allele showed remarkable reductions of promoter reporter activity in INS-1 cells due to the decreased SP1 binding to $-82 /-67$ bp region (Figure 2). These data suggested that the mutation was cosegregated with fasting hyperglycemia due to loss of SP1 binding [123].

Two SNPs, $-6612 \mathrm{G}>\mathrm{A}(\mathrm{rs} 4607517)$ [124,125] and -30G > A (rs1799884) [126-129], in the $\beta G C K$ promoter were significantly associated with fasting plasma glucose level in several populations. Moreover, the $-30 \mathrm{G}>\mathrm{A}$ SNP has been associated with reduced $\beta$-cell function [130], impaired glucose tolerance [131] and T2DM [126]. These data suggested that rare alleles of these two SNPs may also inhibit the $\beta G C K$ transcription. However, functional studies of these two SNPs are needed to clarify cause-effect in terms of $\beta G C K$ transcription.

\section{Conclusions}

Although muscle or adipose tissue have been considered as the principal organs of glucose disposal, immediate handling of hyperglycemia in $\beta$-cells or liver is also important because high levels of glucose are toxic to various tissues. Thus, studies on the regulation of glucose sensors in the liver and $\beta$-cells are important in understanding T2DM and preventing the long-term complications resulting from hyperglycemia. Recent advances in the analytical technologies of genomics and proteomics make it possible to unveil the existence of transcription factors and their physical interactions with DNA or other coregulators.

Deeper understanding of the role of transcription factors involved in the gene regulation of the glucose sensors in the liver and $\beta$-cells may provide important clues in the prevention of the occurrence of hyperglycemia-related complications and development of novel therapeutic drugs combating T2DM, a world-wide epidemic.

\section{Acknowledgements}

We apologize to all the contributors in the field whose works could not be cited due to space limitations. This research was supported by Basic Science Research Program through the National Research Foundation of Korea (NRF) funded by the Ministry of Education, Science and Technology (2009-0080655) and was supported by a grant of the Korea Healthcare technology R\&D Project, Ministry for Health, Welfare \& Family Affairs, Republic of Korea. (A091023).

\section{References}

1. Thorens, B. Glucose sensing and the pathogenesis of obesity and type 2 diabetes. Int. J. Obes. (Lond) 2008, 32, S62-S71. 
2. Magnuson, M.A.; Matschinsky, F.M. Glucokinase as a glucose sensor: Past, present and future; In Glucokinase and Glycemic Disease: From Basics to Novle Therapeutics; Karger: Basel. Switzerland, 2004; pp. 1-17.

3. Tarasov, A.; Dusonchet, J.; Ashcroft, F. Metabolic regulation of the pancreatic beta-cell ATP-sensitive $\mathrm{K}^{+}$channel: A pas de deux. Diabetes 2004, 53, S113-S122.

4. Muoio, D.M.; Newgard, C.B. Mechanisms of disease: molecular and metabolic mechanisms of insulin resistance and beta-cell failure in type 2 diabetes. Nat. Rev. Mol. Cell Biol. 2008, 9, 193-205.

5. Remedi, M.S.; Nichols, C.G. Hyperinsulinism and diabetes: genetic dissection of beta cell metabolism-excitation coupling in mice. Cell Metab. 2009, 10, 442-453.

6. Fajans, S.S.; Bell, G.I.; Polonsky, K.S. Molecular mechanisms and clinical pathophysiology of maturity-onset diabetes of the young. $N$ Engl. J. Med. 2001, 345, 971-980.

7. Vaxillaire, M.; Froguel, P. Monogenic diabetes in the young, pharmacogenetics and relevance to multifactorial forms of type 2 diabetes. Endocr. Rev. 2008, 29, 254-264.

8. O'Rahilly, S. Human genetics illuminates the paths to metabolic disease. Nature 2009, 462, 307-314.

9. Im, S.S.; Kim, S.Y.; Kim, H.I.; Ahn, Y.H. Transcriptional regulation of glucose sensors in pancreatic beta cells and liver. Curr. Diabetes Rev. 2006, 2, 11-18.

10. Mueckler, M.; Kruse, M.; Strube, M.; Riggs, A.C.; Chiu, K.C.; Permutt, M.A. A mutation in the Glut2 glucose transporter gene of a diabetic patient abolishes transport activity. J. Biol. Chem. 1994, 269, 17765-17767.

11. Waeber, G.; Thompson, N.; Haefliger, J.A.; Nicod, P. Characterization of the murine high Km glucose transporter GLUT2 gene and its transcriptional regulation by glucose in a differentiated insulin-secreting cell line. J. Biol. Chem. 1994, 269, 26912-26919.

12. Leturque, A.; Brot-Laroche, E.; Le Gall, M. GLUT2 mutations, translocation, and receptor function in diet sugar managing. Am. J. Physiol. Endocrinol. Metab. 2009, 296, E985-E992.

13. Chen, L.; Alam, T.; Johnson, J.H.; Hughes, S.; Newgard, C.B.; Unger, R.H. Regulation of beta-cell glucose transporter gene expression. Proc. Natl. Acad. Sci. USA 1990, 87, 4088-4092.

14. Postic, C.; Burcelin, R.; Rencurel, F.; Pegorier, J.P.; Loizeau, M.; Girard, J.; Leturque, A. Evidence for a transient inhibitory effect of insulin on GLUT2 expression in the liver: Studies in vivo and in vitro. Biochem. J. 1993, 293, 119-124.

15. Rencurel, F.; Waeber, G.; Antoine, B.; Rocchiccioli, F.; Maulard, P.; Girard, J.; Leturque, A. Requirement of glucose metabolism for regulation of glucose transporter type 2 (GLUT2) gene expression in liver. Biochem. J. 1996, 314, 903-909.

16. Thorens, B.; Wu, Y.J.; Leahy, J.L.; Weir, G.C. The loss of GLUT2 expression by glucose-unresponsive beta cells of $\mathrm{db} / \mathrm{db}$ mice is reversible and is induced by the diabetic environment. J. Clin. Invest. 1992, 90, 77-85.

17. Ohneda, M.; Johnson, J.H.; Inman, L.R.; Chen, L.; Suzuki, K.; Goto, Y.; Alam, T.; Ravazzola, M.; Orci, L.; Unger, R.H. GLUT2 expression and function in beta-cells of GK rats with NIDDM. Dissociation between reductions in glucose transport and glucose-stimulated insulin secretion. Diabetes 1993, 42, 1065-1072. 
18. Stoffel, M.; Froguel, P.; Takeda, J.; Zouali, H.; Vionnet, N.; Nishi, S.; Weber, I.T.; Harrison, R.W.; Pilkis, S.J.; Lesage, S. Human glucokinase gene: isolation, characterization, and identification of two missense mutations linked to early-onset non-insulin-dependent (type 2) diabetes mellitus. Proc. Natl. Acad. Sci. USA 1992, 89, 7698-7702.

19. Postic, C.; Niswender, K.D.; Decaux, J.F.; Parsa, R.; Shelton, K.D.; Gouhot, B.; Pettepher, C.C.; Granner, D.K.; Girard, J.; Magnuson, M.A. Cloning and characterization of the mouse glucokinase gene locus and identification of distal liver-specific DNase I hypersensitive sites. Genomics 1995, 29, 740-750.

20. Williams, C.P.; Granner, D.K.; Magnuson, M.A.; Chalkley, R. Cell specific differences in DNase I hypersensitivity between the two promoters of the rat glucokinase gene. Biochem. Biophys. Res. Commun. 1995, 215, 272-279.

21. Iynedjian, P.B. Molecular physiology of mammalian glucokinase. Cell Mol. Life Sci. 2009, 66, $27-42$.

22. Ahn, Y.H.; Kim, J.W.; Han, G.S.; Lee, B.G.; Kim, Y.S. Cloning and characterization of rat pancreatic beta-cell/liver type glucose transporter gene: a unique exon/intron organization. Arch. Biochem. Biophys. 1995, 323, 387-396.

23. Rahimian, R.; Masih-Khan, E.; Lo, M.; van Breemen, C.; McManus, B.M.; Dube, G.P. Hepatic over-expression of peroxisome proliferator activated receptor gamma2 in the ob/ob mouse model of non-insulin dependent diabetes mellitus. Mol. Cell Biochem. 2001, 224, $29-37$.

24. Kim, H.I.; Cha, J.Y.; Kim, S.Y.; Kim, J.W.; Roh, K.J.; Seong, J.K.; Lee, N.T.; Choi, K.Y.; Kim, K.S.; Ahn, Y.H. Peroxisomal proliferator-activated receptor-gamma upregulates glucokinase gene expression in beta-cells. Diabetes 2002, 51, 676-685.

25. Shih, D.Q.; Screenan, S.; Munoz, K.N.; Philipson, L.; Pontoglio, M.; Yaniv, M.; Polonsky, K.S.; Stoffel, M. Loss of HNF-1alpha function in mice leads to abnormal expression of genes involved in pancreatic islet development and metabolism. Diabetes 2001, 50, 2472-2480.

26. Cha, J.Y.; Kim, H.; Kim, K.S.; Hur, M.W.; Ahn, Y. Identification of transacting factors responsible for the tissue-specific expression of human glucose transporter type 2 isoform gene. Cooperative role of hepatocyte nuclear factors 1alpha and 3beta. J. Biol. Chem. 2000, 275, $18358-18365$.

27. Freitas, H.S.; Schaan, B.D.; David-Silva, A.; Sabino-Silva, R.; Okamoto, M.M.; Alves-Wagner, A.B.; Mori, R.C.; Machado, U.F. SLC2A2 gene expression in kidney of diabetic rats is regulated by HNF-1alpha and HNF-3beta. Mol. Cell Endocrinol. 2009, 305, 63-70.

28. Ban, N.; Yamada, Y.; Someya, Y.; Miyawaki, K.; Ihara, Y.; Hosokawa, M.; Toyokuni, S.; Tsuda, K.; Seino, Y. Hepatocyte nuclear factor-1alpha recruits the transcriptional co-activator p300 on the GLUT2 gene promoter. Diabetes 2002, 51, 1409-1418.

29. Rausa, F.M.; Tan, Y.; Zhou, H.; Yoo, K.W.; Stolz, D.B.; Watkins, S.C.; Franks, R.R.; Unterman, T.G.; Costa, R.H. Elevated levels of hepatocyte nuclear factor 3 beta in mouse hepatocytes influence expression of genes involved in bile acid and glucose homeostasis. Mol. Cell Biol. 2000, 20, 8264-8282.

30. Tan, Y.; Hughes, D.; Wang, X.; Costa, R.H. Adenovirus-mediated increase in HNF-3beta or HNF-3alpha shows differences in levels of liver glycogen and gene expression. Hepatology 2002, $35,30-39$. 
31. Tan, Y.; Adami, G.; Costa, R.H. Maintaining HNF6 expression prevents AdHNF3beta-mediated decrease in hepatic levels of Glut-2 and glycogen. Hepatology 2002, 35, 790-798.

32. Rubins, N.E.; Friedman, J.R.; Le, P.P.; Zhang, L.; Brestelli, J.; Kaestner, K.H. Transcriptional networks in the liver: hepatocyte nuclear factor 6 function is largely independent of Foxa2. Mol. Cell Biol. 2005, 25, 7069-7077.

33. Lee, C.S.; Sund, N.J.; Vatamaniuk, M.Z.; Matschinsky, F.M.; Stoffers, D.A.; Kaestner, K.H. Foxa2 controls Pdx1 gene expression in pancreatic beta-cells in vivo. Diabetes 2002, 51, 2546-2551.

34. Shen, W.; Scearce, L.M.; Brestelli, J.E.; Sund, N.J.; Kaestner, K.H. Foxa3 (hepatocyte nuclear factor 3 gamma ) is required for the regulation of hepatic GLUT2 expression and the maintenance of glucose homeostasis during a prolonged fast. J. Biol. Chem. 2001, 276, 42812-42817.

35. Stoffel, M.; Duncan, S.A. The maturity-onset diabetes of the young (MODY1) transcription factor HNF4alpha regulates expression of genes required for glucose transport and metabolism. Proc. Natl. Acad. Sci. USA 1997, 94, 13209-13214.

36. Wang, H.; Maechler, P.; Antinozzi, P.A.; Hagenfeldt, K.A.; Wollheim, C.B. Hepatocyte nuclear factor 4alpha regulates the expression of pancreatic beta-cell genes implicated in glucose metabolism and nutrient-induced insulin secretion. J. Biol. Chem. 2000, 275, 35953-35959.

37. Babu, D.A.; Deering, T.G.; Mirmira, R.G. A feat of metabolic proportions: Pdx1 orchestrates islet development and function in the maintenance of glucose homeostasis. Mol. Genet. Metab. 2007, $92,43-55$.

38. Waeber, G.; Thompson, N.; Nicod, P.; Bonny, C. Transcriptional activation of the GLUT2 gene by the IPF-1/STF-1/IDX-1 homeobox factor. Mol. Endocrinol. 1996, 10, 1327-1334.

39. Ahlgren, U.; Jonsson, J.; Jonsson, L.; Simu, K.; Edlund, H. beta-cell-specific inactivation of the mouse Ipf1/Pdx1 gene results in loss of the beta-cell phenotype and maturity onset diabetes. Genes Dev. 1998, 12, 1763-1768.

40. Lottmann, H.; Vanselow, J.; Hessabi, B.; Walther, R. The Tet-On system in transgenic mice: inhibition of the mouse pdx-1 gene activity by antisense RNA expression in pancreatic beta-cells. J. Mol. Med. 2001, 79, 321-328.

41. Brissova, M.; Shiota, M.; Nicholson, W.E.; Gannon, M.; Knobel, S.M.; Piston, D.W.; Wright, C.V.; Powers, A.C. Reduction in pancreatic transcription factor PDX-1 impairs glucose-stimulated insulin secretion. J. Biol. Chem. 2002, 277, 11225-11232.

42. Chakrabarti, S.K.; James, J.C.; Mirmira, R.G. Quantitative assessment of gene targeting in vitro and in vivo by the pancreatic transcription factor, $\mathrm{Pdx} 1$. Importance of chromatin structure in directing promoter binding. J. Biol. Chem. 2002, 277, 13286-13293.

43. Ueda, T.; Furusawa, T.; Kurahashi, T.; Tessarollo, L.; Bustin, M. The nucleosome binding protein HMGN3 modulates the transcription profile of pancreatic beta cells and affects insulin secretion. Mol. Cell Biol. 2009, 29, 5264-5276.

44. Ben-Shushan, E.; Marshak, S.; Shoshkes, M.; Cerasi, E.; Melloul, D. A pancreatic beta-cell-specific enhancer in the human PDX-1 gene is regulated by hepatocyte nuclear factor 3beta (HNF-3beta), HNF-1alpha, and SPs transcription factors. J. Biol. Chem. 2001, 276, 17533-17540. 
45. Samaras, S.E.; Cissell, M.A.; Gerrish, K.; Wright, C.V.; Gannon, M.; Stein, R. Conserved sequences in a tissue-specific regulatory region of the pdx-1 gene mediate transcription in Pancreatic beta cells: role for hepatocyte nuclear factor 3 beta and Pax6. Mol. Cell Biol. 2002, 22, $4702-4713$.

46. Patane, G.; Kaneto, H.; Toschi, E.; Sharma, A.; Gupta, S.; Weir, G.C. Induction of Mad expression leads to augmentation of insulin gene transcription. Biochem. Biophys. Res. Commun. 2003, 303, 1199-1208.

47. Eto, K.; Kaur, V.; Thomas, M.K. Regulation of insulin gene transcription by the immediate-early growth response gene Egr-1. Endocrinology 2006, 147, 2923-2935.

48. Eto, K.; Kaur, V.; Thomas, M.K. Regulation of pancreas duodenum homeobox-1 expression by early growth response-1. J. Biol. Chem. 2007, 282, 5973-5983.

49. Samaras, S.E.; Zhao, L.; Means, A.; Henderson, E.; Matsuoka, T.A.; Stein, R. The islet beta cell-enriched RIPE3b1/Maf transcription factor regulates pdx-1 expression. J. Biol. Chem. 2003, 278, 12263-12270.

50. Babu, D.A.; Chakrabarti, S.K.; Garmey, J.C.; Mirmira, R.G. Pdx1 and BETA2/NeuroD1 participate in a transcriptional complex that mediates short-range DNA looping at the insulin gene. J. Biol. Chem. 2008, 283, 8164-8172.

51. Sun, Y.; Zhang, L.; Gu, H.F.; Han, W.; Ren, M.; Wang, F.; Gong, B.; Wang, L.; Guo, H.; Xin, W.; Zhao, J.; Gao, L. Peroxisome proliferator-activated receptor-alpha regulates the expression of pancreatic/duodenal homeobox-1 in rat insulinoma (INS-1) cells and ameliorates glucose-induced insulin secretion impaired by palmitate. Endocrinology 2008, 149, 662-671.

52. Moibi, J.A.; Gupta, D.; Jetton, T.L.; Peshavaria, M.; Desai, R.; Leahy, J.L. Peroxisome proliferator-activated receptor-gamma regulates expression of PDX-1 and NKX6.1 in INS-1 cells. Diabetes 2007, 56, 88-95.

53. Buteau, J.; Shlien, A.; Foisy, S.; Accili, D. Metabolic diapause in pancreatic beta-cells expressing a gain-of-function mutant of the forkhead protein Foxo1. J. Biol. Chem. 2007, 282, 287-293.

54. Kitamura, T.; Nakae, J.; Kitamura, Y.; Kido, Y.; Biggs, W.H., III; Wright, C.V.; White, M.F.; Arden, K.C.; Accili, D. The forkhead transcription factor Foxo1 links insulin signaling to Pdx1 regulation of pancreatic beta cell growth. J. Clin. Invest. 2002, 110, 1839-1847.

55. Artner, I.; Le Lay, J.; Hang, Y.; Elghazi, L.; Schisler, J.C.; Henderson, E.; Sosa-Pineda, B.; Stein, R. MafB: An activator of the glucagon gene expressed in developing islet alpha- and beta-cells. Diabetes 2006, 55, 297-304.

56. Nishimura, W.; Kondo, T.; Salameh, T.; El Khattabi, I.; Dodge, R.; Bonner-Weir, S.; Sharma, A. A switch from MafB to MafA expression accompanies differentiation to pancreatic beta-cells. Dev. Biol. 2006, 293, 526-539.

57. Artner, I.; Blanchi, B.; Raum, J.C.; Guo, M.; Kaneko, T.; Cordes, S.; Sieweke, M.; Stein, R. MafB is required for islet beta cell maturation. Proc. Natl. Acad. Sci. USA 2007, 104, 3853-3858.

58. Zhang, C.; Moriguchi, T.; Kajihara, M.; Esaki, R.; Harada, A.; Shimohata, H.; Oishi, H.; Hamada, M.; Morito, N.; Hasegawa, K.; Kudo, T.; Engel, J.D.; Yamamoto, M.; Takahashi, S. MafA is a key regulator of glucose-stimulated insulin secretion. Mol. Cell Biol. 2005, 25, 4969-4976. 
59. Im, S.S.; Kim, J.W.; Kim, T.H.; Song, X.L.; Kim, S.Y.; Kim, H.I.; Ahn, Y.H. Identification and characterization of peroxisome proliferator response element in the mouse GLUT2 promoter. Exp. Mol. Med. 2005, 37, 101-110.

60. Kim, H.I.; Kim, J.W.; Kim, S.H.; Cha, J.Y.; Kim, K.S.; Ahn, Y.H. Identification and functional characterization of the peroxisomal proliferator response element in rat GLUT2 promoter. Diabetes 2000, 49, 1517-1524.

61. Kim, H.I.; Ahn, Y.H. Role of peroxisome proliferator-activated receptor-gamma in the glucose-sensing apparatus of liver and beta-cells. Diabetes 2004, 53, S60-S65.

62. Kim, H.S.; Noh, J.H.; Hong, S.H.; Hwang, Y.C.; Yang, T.Y.; Lee, M.S.; Kim, K.W.; Lee, M.K. Rosiglitazone stimulates the release and synthesis of insulin by enhancing GLUT-2, glucokinase and BETA2/NeuroD expression. Biochem. Biophys. Res. Commun. 2008, 367, 623-629.

63. Yajima, K.; Hirose, H.; Fujita, H.; Seto, Y.; Ukeda, K.; Miyashita, K.; Kawai, T.; Yamamoto, Y.; Ogawa, T.; Yamada, T.; Saruta, T. Combination therapy with PPARgamma and PPARalpha agonists increases glucose-stimulated insulin secretion in $\mathrm{db} / \mathrm{db}$ mice. Am. J. Physiol. Endocrinol. Metab. 2003, 284, E966-E971.

64. Evans-Molina, C.; Robbins, R.D.; Kono, T.; Tersey, S.A.; Vestermark, G.L.; Nunemaker, C.S.; Garmey, J.C.; Deering, T.G.; Keller, S.R.; Maier, B.; Mirmira, R.G. Peroxisome proliferator-activated receptor gamma activation restores islet function in diabetic mice through reduction of endoplasmic reticulum stress and maintenance of euchromatin structure. Mol. Cell Biol. 2009, 29, 2053-2067.

65. Wang, M.Y.; Koyama, K.; Shimabukuro, M.; Mangelsdorf, D.; Newgard, C.B.; Unger, R.H. Overexpression of leptin receptors in pancreatic islets of Zucker diabetic fatty rats restores GLUT-2, glucokinase, and glucose-stimulated insulin secretion. Proc. Natl. Acad. Sci. USA 1998, 95, 11921-11926.

66. Yessoufou, A.; Ategbo, J.M.; Attakpa, E.; Hichami, A.; Moutairou, K.; Dramane, K.L.; Khan, N.A. Peroxisome proliferator-activated receptor-alpha modulates insulin gene transcription factors and inflammation in adipose tissues in mice. Mol. Cell Biochem. 2009, 323, 101-111.

67. Asano, T.; Katagiri, H.; Tsukuda, K.; Lin, J.L.; Ishihara, H.; Yazaki, Y.; Oka, Y. Upregulation of GLUT2 mRNA by glucose, mannose, and fructose in isolated rat hepatocytes. Diabetes 1992, 41, $22-25$.

68. Schuit, F.; Flamez, D.; De Vos, A.; Pipeleers, D. Glucose-regulated gene expression maintaining the glucose-responsive state of beta-cells. Diabetes 2002, 51, S326-S332.

69. Im, S.S.; Kang, S.Y.; Kim, S.Y.; Kim, H.I.; Kim, J.W.; Kim, K.S.; Ahn, Y.H. Glucose-stimulated upregulation of GLUT2 gene is mediated by sterol response element-binding protein-1c in the hepatocytes. Diabetes 2005, 54, 1684-1691.

70. Diraison, F.; Ravier, M.A.; Richards, S.K.; Smith, R.M.; Shimano, H.; Rutter, G.A. SREBP1 is required for the induction by glucose of pancreatic beta-cell genes involved in glucose sensing. $J$. Lipid Res. 2008, 49, 814-822.

71. Rencurel, F.; Waeber, G.; Bonny, C.; Antoine, B.; Maulard, P.; Girard, J.; Leturque, A. cAMP prevents the glucose-mediated stimulation of GLUT2 gene transcription in hepatocytes. Biochem. J. 1997, 322, 441-448. 
72. Pei, L.; Waki, H.; Vaitheesvaran, B.; Wilpitz, D.C.; Kurland, I.J.; Tontonoz, P. NR4A orphan nuclear receptors are transcriptional regulators of hepatic glucose metabolism. Nat. Med. 2006, 12, 1048-1055.

73. Barthel, A.; Schmoll, D.; Unterman, T.G. FoxO proteins in insulin action and metabolism. Trends Endocrinol. Metab. 2005, 16, 183-189.

74. Kim, J.W.; Ahn, Y.H. CCAAT/enhancer binding protein regulates the promoter activity of the rat GLUT2 glucose transporter gene in liver cells. Biochem. J. 1998, 336, 83-90.

75. Kawamura, Y.; Tanaka, Y.; Kawamori, R.; Maeda, S. Overexpression of Kruppel-like factor 7 regulates adipocytokine gene expressions in human adipocytes and inhibits glucose-induced insulin secretion in pancreatic beta-cell line. Mol. Endocrinol. 2006, 20, 844-856.

76. Odom, D.T.; Dowell, R.D.; Jacobsen, E.S.; Gordon, W.; Danford, T.W.; MacIsaac, K.D.; Rolfe, P.A.; Conboy, C.M.; Gifford, D.K.; Fraenkel, E. Tissue-specific transcriptional regulation has diverged significantly between human and mouse. Nat. Genet. 2007, 39, 730-732.

77. Matschinsky, F.; Liang, Y.; Kesavan, P.; Wang, L.; Froguel, P.; Velho, G.; Cohen, D.; Permutt, M.A.; Tanizawa, Y.; Jetton, T.L. Glucokinase as pancreatic beta cell glucose sensor and diabetes gene. J. Clin. Invest. 1993, 92, 2092-2098.

78. Leibiger, B.; Leibiger, I.B.; Moede, T.; Kemper, S.; Kulkarni, R.N.; Kahn, C.R.; de Vargas, L.M.; Berggren, P.O. Selective insulin signaling through $A$ and $B$ insulin receptors regulates transcription of insulin and glucokinase genes in pancreatic beta cells. Mol. Cell 2001, 7, 559-570.

79. Da Silva Xavier, G.; Qian, Q.; Cullen, P.J.; Rutter, G.A. Distinct roles for insulin and insulin-like growth factor-1 receptors in pancreatic beta-cell glucose sensing revealed by RNA silencing. Biochem. J. 2004, 377, 149-158.

80. Iynedjian, P.B.; Pilot, P.R.; Nouspikel, T.; Milburn, J.L.; Quaade, C.; Hughes, S.; Ucla, C.; Newgard, C.B. Differential expression and regulation of the glucokinase gene in liver and islets of Langerhans. Proc. Natl. Acad. Sci. USA 1989, 86, 7838-7842.

81. da Silva Xavier, G.; Varadi, A.; Ainscow, E.K.; Rutter, G.A. Regulation of gene expression by glucose in pancreatic beta-cells (MIN6) via insulin secretion and activation of phosphatidylinositol 3'-kinase. J. Biol. Chem. 2000, 275, 36269-36277.

82. Shelton, K.D.; Franklin, A.J.; Khoor, A.; Beechem, J.; Magnuson, M.A. Multiple elements in the upstream glucokinase promoter contribute to transcription in insulinoma cells. Mol. Cell Biol. 1992, 12, 4578-4589.

83. Moates, J.M.; Shelton, K.D.; Magnuson, M.A. Characterization of the Pal motifs in the upstream glucokinase promoter: binding of a cell type-specific protein complex correlates with transcriptional activation. Mol. Endocrinol. 1996, 10, 723-731.

84. Macfarlane, W.M.; Smith, S.B.; James, R.F.; Clifton, A.D.; Doza, Y.N.; Cohen, P.; Docherty, K. The p38/reactivating kinase mitogen-activated protein kinase cascade mediates the activation of the transcription factor insulin upstream factor 1 and insulin gene transcription by high glucose in pancreatic beta-cells. J. Biol. Chem. 1997, 272, 20936-20944.

85. Rafiq, I.; Kennedy, H.J.; Rutter, G.A. Glucose-dependent translocation of insulin promoter factor-1 (IPF-1) between the nuclear periphery and the nucleoplasm of single MIN6 beta-cells. J. Biol. Chem. 1998, 273, 23241-23247. 
86. Habener, J.F.; Kemp, D.M.; Thomas, M.K. Minireview: transcriptional regulation in pancreatic development. Endocrinology 2005, 146, 1025-1034.

87. Watada, H.; Kajimoto, Y.; Umayahara, Y.; Matsuoka, T.; Kaneto, H.; Fujitani, Y.; Kamada, T.; Kawamori, R.; Yamasaki, Y. The human glucokinase gene beta-cell-type promoter: an essential role of insulin promoter factor 1/PDX-1 in its activation in HIT-T15 cells. Diabetes 1996, 45, $1478-1488$.

88. Moates, J.M.; Nanda, S.; Cissell, M.A.; Tsai, M.J.; Stein, R. BETA2 activates transcription from the upstream glucokinase gene promoter in islet beta-cells and gut endocrine cells. Diabetes 2003, 52, 403-408.

89. Kim, J.Y.; Chu, K.; Kim, H.J.; Seong, H.A.; Park, K.C.; Sanyal, S.; Takeda, J.; Ha, H.; Shong, M.; Tsai, M.J.; Choi, H.S. Orphan nuclear receptor small heterodimer partner, a novel corepressor for a basic helix-loop-helix transcription factor BETA2/neuroD. Mol. Endocrinol. 2004, 18, 776-790.

90. Yoshida, K.; Murao, K.; Imachi, H.; Cao, W.M.; Yu, X.; Li, J.; Ahmed, R.A.; Kitanaka, N.; Wong, N.C.; Unterman, T.G.; Magnuson, M.A.; Ishida, T. Pancreatic glucokinase is activated by insulin-like growth factor-I. Endocrinology 2007, 148, 2904-2913.

91. Cissell, M.A.; Zhao, L.; Sussel, L.; Henderson, E.; Stein, R. Transcription factor occupancy of the insulin gene in vivo. Evidence for direct regulation by Nkx2.2. J. Biol. Chem. 2003, 278, 751-756.

92. Sussel, L.; Kalamaras, J.; Hartigan-O'Connor, D.J.; Meneses, J.J.; Pedersen, R.A.; Rubenstein, J.L.; German, M.S. Mice lacking the homeodomain transcription factor Nkx2.2 have diabetes due to arrested differentiation of pancreatic beta cells. Development 1998, 125, 2213-2221.

93. Iynedjian, P.B.; Gjinovci, A.; Renold, A.E. Stimulation by insulin of glucokinase gene transcription in liver of diabetic rats. J. Biol. Chem. 1988, 263, 740-744.

94. Iynedjian, P.B.; Jotterand, D.; Nouspikel, T.; Asfari, M.; Pilot, P.R. Transcriptional induction of glucokinase gene by insulin in cultured liver cells and its repression by the glucagon-cAMP system. J. Biol. Chem. 1989, 264, 21824-21829.

95. Iynedjian, P.B.; Roth, R.A.; Fleischmann, M.; Gjinovci, A. Activation of protein kinase B/cAkt in hepatocytes is sufficient for the induction of expression of the gene encoding glucokinase. Biochem. J. 2000, 351, 621-627.

96. Matsumoto, M.; Ogawa, W.; Teshigawara, K.; Inoue, H.; Miyake, K.; Sakaue, H.; Kasuga, M. Role of the insulin receptor substrate 1 and phosphatidylinositol 3-kinase signaling pathway in insulin-induced expression of sterol regulatory element binding protein 1c and glucokinase genes in rat hepatocytes. Diabetes 2002, 51, 1672-1680.

97. Kim, J.B.; Sarraf, P.; Wright, M.; Yao, K.M.; Mueller, E.; Solanes, G.; Lowell, B.B.; Spiegelman, B.M. Nutritional and insulin regulation of fatty acid synthetase and leptin gene expression through ADD1/SREBP1. J. Clin. Invest. 1998, 101, 1-9.

98. Foretz, M.; Pacot, C.; Dugail, I.; Lemarchand, P.; Guichard, C.; Le Liepvre, X.; Berthelier-Lubrano, C.; Spiegelman, B.; Kim, J.B.; Ferre, P.; Foufelle, F. ADD1/SREBP-1c is required in the activation of hepatic lipogenic gene expression by glucose. Mol. Cell Biol. 1999, 19, 3760-3768.

99. Becard, D.; Hainault, I.; Azzout-Marniche, D.; Bertry-Coussot, L.; Ferre, P.; Foufelle, F. Adenovirus-mediated overexpression of sterol regulatory element binding protein-1c mimics 
insulin effects on hepatic gene expression and glucose homeostasis in diabetic mice. Diabetes 2001, 50, 2425-2430.

100. Foretz, M.; Guichard, C.; Ferre, P.; Foufelle, F. Sterol regulatory element binding protein-1c is a major mediator of insulin action on the hepatic expression of glucokinase and lipogenesis-related genes. Proc. Natl. Acad. Sci. USA 1999, 96, 12737-12742.

101. Kim, S.Y.; Kim, H.I.; Kim, T.H.; Im, S.S.; Park, S.K.; Lee, I.K.; Kim, K.S.; Ahn, Y.H. SREBP-1c mediates the insulin-dependent hepatic glucokinase expression. J. Biol. Chem. 2004, 279, 30823-30829.

102. Liang, G.; Yang, J.; Horton, J.D.; Hammer, R.E.; Goldstein, J.L.; Brown, M.S. Diminished hepatic response to fasting/refeeding and liver $\mathrm{X}$ receptor agonists in mice with selective deficiency of sterol regulatory element-binding protein-1c. J. Biol. Chem. 2002, 277, 9520-9528.

103. Gregori, C.; Guillet-Deniau, I.; Girard, J.; Decaux, J.F.; Pichard, A.L. Insulin regulation of glucokinase gene expression: Evidence against a role for sterol regulatory element binding protein 1 in primary hepatocytes. FEBS Lett. 2006, 580, 410-414.

104. Hansmannel, F.; Mordier, S.; Iynedjian, P.B. Insulin induction of glucokinase and fatty acid synthase in hepatocytes: analysis of the roles of sterol-regulatory-element-binding protein-1c and liver X receptor. Biochem. J. 2006, 399, 275-283.

105. Yamagata, K.; Furuta, H.; Oda, N.; Kaisaki, P.J.; Menzel, S.; Cox, N.J.; Fajans, S.S.; Signorini, S.; Stoffel, M.; Bell, G.I. Mutations in the hepatocyte nuclear factor-4alpha gene in maturity-onset diabetes of the young (MODY1). Nature 1996, 384, 458-460.

106. Hirota, K.; Sakamaki, J.; Ishida, J.; Shimamoto, Y.; Nishihara, S.; Kodama, N.; Ohta, K.; Yamamoto, M.; Tanimoto, K.; Fukamizu, A. A combination of HNF-4 and Foxo1 is required for reciprocal transcriptional regulation of glucokinase and glucose-6-phosphatase genes in response to fasting and feeding. J. Biol. Chem. 2008, 283, 32432-32441.

107. Roth, U.; Jungermann, K.; Kietzmann, T. Activation of glucokinase gene expression by hepatic nuclear factor 4alpha in primary hepatocytes. Biochem. J. 2002, 365, 223-228.

108. Kietzmann, T.; Samoylenko, A.; Roth, U.; Jungermann, K. Hypoxia-inducible factor-1 and hypoxia response elements mediate the induction of plasminogen activator inhibitor-1 gene expression by insulin in primary rat hepatocytes. Blood 2003, 101, 907-914.

109. Roth, U.; Curth, K.; Unterman, T.G.; Kietzmann, T. The transcription factors HIF-1 and HNF-4 and the coactivator p300 are involved in insulin-regulated glucokinase gene expression via the phosphatidylinositol 3-kinase/protein kinase B pathway. J. Biol. Chem. 2004, 279, 2623-2631.

110. Kietzmann, T.; Roth, U.; Freimann, S.; Jungermann, K. Arterial oxygen partial pressures reduce the insulin-dependent induction of the perivenously located glucokinase in rat hepatocyte cultures: mimicry of arterial oxygen pressures by H2O2. Biochem. J. 1997, 321, 17-20.

111. Storz, P.; Doppler, H.; Pfizenmaier, K.; Muller, G. Insulin selectively activates STAT5b, but not STAT5a, via a JAK2-independent signalling pathway in Kym-1 rhabdomyosarcoma cells. FEBS Lett. 1999, 464, 159-163.

112. Sadowski, C.L.; Choi, T.S.; Le, M.; Wheeler, T.T.; Wang, L.H.; Sadowski, H.B. Insulin Induction of SOCS-2 and SOCS-3 mRNA expression in C2C12 Skeletal Muscle Cells Is Mediated by Stat5*. J. Biol. Chem. 2001, 276, 20703-20710. 
113. Sawka-Verhelle, D.; Tartare-Deckert, S.; Decaux, J.F.; Girard, J.; Van Obberghen, E. Stat 5B, activated by insulin in a Jak-independent fashion, plays a role in glucokinase gene transcription. Endocrinology 2000, 141, 1977-1988.

114. Ribaux, P.; Gjinovci, A.; Sadowski, H.B.; Iynedjian, P.B. Discrimination between signaling pathways in regulation of specific gene expression by insulin and growth hormone in hepatocytes. Endocrinology 2002, 143, 3766-3772.

115. Ganjam, G.K.; Dimova, E.Y.; Unterman, T.G.; Kietzmann, T. FoxO1 and HNF-4 are involved in regulation of hepatic glucokinase gene expression by resveratrol. J. Biol. Chem. 2009, 284, 30783-30797.

116. Iynedjian, P.B. Identification of upstream stimulatory factor as transcriptional activator of the liver promoter of the glucokinase gene. Biochem. J. 1998, 333, 705-712.

117. Kim, S.Y.; Kim, H.I.; Park, S.K.; Im, S.S.; Li, T.; Cheon, H.G.; Ahn, Y.H. Liver glucokinase can be activated by peroxisome proliferator-activated receptor-gamma. Diabetes 2004, 53, S66-S70.

118. Kim, T.H.; Kim, H.; Park, J.M.; Im, S.S.; Bae, J.S.; Kim, M.Y.; Yoon, H.G.; Cha, J.Y.; Kim, K.S.; Ahn, Y.H. Interrelationship between liver $\mathrm{X}$ receptor alpha, sterol regulatory element-binding protein-1c, peroxisome proliferator-activated receptor gamma, and small heterodimer partner in the transcriptional regulation of glucokinase gene expression in liver. J. Biol. Chem. 2009, 284, 15071-15083.

119. Lemaigre, F.P.; Durviaux, S.M.; Truong, O.; Lannoy, V.J.; Hsuan, J.J.; Rousseau, G.G. Hepatocyte nuclear factor 6, a transcription factor that contains a novel type of homeodomain and a single cut domain. Proc. Natl. Acad. Sci. USA 1996, 93, 9460-9464.

120. Lannoy, V.J.; Decaux, J.F.; Pierreux, C.E.; Lemaigre, F.P.; Rousseau, G.G. Liver glucokinase gene expression is controlled by the onecut transcription factor hepatocyte nuclear factor-6. Diabetologia 2002, 45, 1136-1141.

121. Moller, A.M.; Jensen, N.M.; Pildal, J.; Drivsholm, T.; Borch-Johnsen, K.; Urhammer, S.A.; Hansen, T.; Pedersen, O. Studies of genetic variability of the glucose transporter 2 promoter in patients with type 2 diabetes mellitus. J. Clin. Endocrinol. Metab. 2001, 86, 2181-2186.

122. Laukkanen, O.; Lindstrom, J.; Eriksson, J.; Valle, T.T.; Hamalainen, H.; Ilanne-Parikka, P.; Keinanen-Kiukaanniemi, S.; Tuomilehto, J.; Uusitupa, M.; Laakso, M. Polymorphisms in the SLC2A2 (GLUT2) gene are associated with the conversion from impaired glucose tolerance to type 2 diabetes: The Finnish Diabetes Prevention Study. Diabetes 2005, 54, 2256-2260.

123. Gasperikova, D.; Tribble, N.D.; Stanik, J.; Huckova, M.; Misovicova, N.; van de Bunt, M.; Valentinova, L.; Barrow, B.A.; Barak, L.; Dobransky, R.; Bereczkova, E.; Michalek, J.; Wicks, K.; Colclough, K.; Knight, J.C.; Ellard, S.; Klimes, I.; Gloyn, A.L. Identification of a novel beta-cell glucokinase $(\mathrm{GCK})$ promoter mutation $(-71 \mathrm{G}>\mathrm{NC})$ that modulates $\mathrm{GCK}$ gene expression through loss of allele-specific Sp1 binding causing mild fasting hyperglycemia in humans. Diabetes 2009, 58, 1929-1935.

124. Prokopenko, I.; Langenberg, C.; Florez, J.C.; Saxena, R.; Soranzo, N.; Thorleifsson, G.; Loos, R.J.; Manning, A.K.; Jackson, A.U.; Aulchenko, Y.; Potter, S.C.; Erdos, M.R.; Sanna, S.; Hottenga, J.J.; Wheeler, E.; Kaakinen, M.; Lyssenko, V.; Chen, W.M.; Ahmadi, K.; Beckmann, J.S.; Bergman, R.N.; Bochud, M.; Bonnycastle, L.L.; Buchanan, T.A.; Cao, A.; Cervino, A.; Coin, L.; Collins, F.S.; Crisponi, L.; de Geus, E.J.; Dehghan, A.; Deloukas, P.; Doney, A.S.; 
Elliott, P.; Freimer, N.; Gateva, V.; Herder, C.; Hofman, A.; Hughes, T.E.; Hunt, S.; Illig, T.; Inouye, M.; Isomaa, B.; Johnson, T.; Kong, A.; Krestyaninova, M.; Kuusisto, J.; Laakso, M.; Lim, N.; Lindblad, U.; Lindgren, C.M.; McCann, O.T.; Mohlke, K.L.; Morris, A.D.; Naitza, S.; Orru, M.; Palmer, C.N.; Pouta, A.; Randall, J.; Rathmann, W.; Saramies, J.; Scheet, P.; Scott, L.J.; Scuteri, A.; Sharp, S.; Sijbrands, E.; Smit, J.H.; Song, K.; Steinthorsdottir, V.; Stringham, H.M.; Tuomi, T.; Tuomilehto, J.; Uitterlinden, A.G.; Voight, B.F.; Waterworth, D.; Wichmann, H.E.; Willemsen, G.; Witteman, J.C.; Yuan, X.; Zhao, J.H.; Zeggini, E.; Schlessinger, D.; Sandhu, M.; Boomsma, D.I.; Uda, M.; Spector, T.D.; Penninx, B.W.; Altshuler, D.; Vollenweider, P.; Jarvelin, M.R.; Lakatta, E.; Waeber, G.; Fox, C.S.; Peltonen, L.; Groop, L.C.; Mooser, V.; Cupples, L.A.; Thorsteinsdottir, U.; Boehnke, M.; Barroso, I.; Van Duijn, C.; Dupuis, J.; Watanabe, R.M.; Stefansson, K.; McCarthy, M.I.; Wareham, N.J.; Meigs, J.B.; Abecasis, G.R. Variants in MTNR1B influence fasting glucose levels. Nat. Genet. 2009, 41, 77-81.

125. Dupuis, J.; Langenberg, C.; Prokopenko, I.; Saxena, R.; Soranzo, N.; Jackson, A.U.; Wheeler, E.; Glazer, N.L.; Bouatia-Naji, N.; Gloyn, A.L.; Lindgren, C.M.; Magi, R.; Morris, A.P.; Randall, J.; Johnson, T.; Elliott, P.; Rybin, D.; Thorleifsson, G.; Steinthorsdottir, V.; Henneman, P.; Grallert, H.; Dehghan, A.; Hottenga, J.J.; Franklin, C.S.; Navarro, P.; Song, K.; Goel, A.; Perry, J.R.; Egan, J.M.; Lajunen, T.; Grarup, N.; Sparso, T.; Doney, A.; Voight, B.F.; Stringham, H.M.; Li, M.; Kanoni, S.; Shrader, P.; Cavalcanti-Proenca, C.; Kumari, M.; Qi, L.; Timpson, N.J.; Gieger, C.; Zabena, C.; Rocheleau, G.; Ingelsson, E.; An, P.; O’Connell, J.; Luan, J.; Elliott, A.; McCarroll, S.A.; Payne, F.; Roccasecca, R.M.; Pattou, F.; Sethupathy, P.; Ardlie, K.; Ariyurek, Y.; Balkau, B.; Barter, P.; Beilby, J.P.; Ben-Shlomo, Y.; Benediktsson, R.; Bennett, A.J.; Bergmann, S.; Bochud, M.; Boerwinkle, E.; Bonnefond, A.; Bonnycastle, L.L.; Borch-Johnsen, K.; Bottcher, Y.; Brunner, E.; Bumpstead, S.J.; Charpentier, G.; Chen, Y.D.; Chines, P.; Clarke, R.; Coin, L.J.; Cooper, M.N.; Cornelis, M.; Crawford, G.; Crisponi, L.; Day, I.N.; de Geus, E.J.; Delplanque, J.; Dina, C.; Erdos, M. R.; Fedson, A. C.; Fischer-Rosinsky, A.; Forouhi, N. G.; Fox, C.S.; Frants, R.; Franzosi, M.G.; Galan, P.; Goodarzi, M.O.; Graessler, J.; Groves, C.J.; Grundy, S.; Gwilliam, R.; Gyllensten, U.; Hadjadj, S.; Hallmans, G.; Hammond, N.; Han, X.; Hartikainen, A.L.; Hassanali, N.; Hayward, C.; Heath, S.C.; Hercberg, S.; Herder, C.; Hicks, A.A.; Hillman, D.R.; Hingorani, A.D.; Hofman, A.; Hui, J.; Hung, J.; Isomaa, B.; Johnson, P.R.; Jorgensen, T.; Jula, A.; Kaakinen, M.; Kaprio, J.; Kesaniemi, Y.A.; Kivimaki, M.; Knight, B.; Koskinen, S.; Kovacs, P.; Kyvik, K.O.; Lathrop, G.M.; Lawlor, D.A.; Le Bacquer, O.; Lecoeur, C.; Li, Y.; Lyssenko, V.; Mahley, R.; Mangino, M.; Manning, A.K.; Martinez-Larrad, M.T.; McAteer, J.B.; McCulloch, L.J.; McPherson, R.; Meisinger, C.; Melzer, D.; Meyre, D.; Mitchell, B.D.; Morken, M.A.; Mukherjee, S.; Naitza, S.; Narisu, N.; Neville, M.J.; Oostra, B.A.; Orru, M.; Pakyz, R.; Palmer, C.N.; Paolisso, G.; Pattaro, C.; Pearson, D.; Peden, J.F.; Pedersen, N.L.; Perola, M.; Pfeiffer, A.F.; Pichler, I.; Polasek, O.; Posthuma, D.; Potter, S.C.; Pouta, A.; Province, M.A.; Psaty, B.M.; Rathmann, W.; Rayner, N.W.; Rice, K.; Ripatti, S.; Rivadeneira, F.; Roden, M.; Rolandsson, O.; Sandbaek, A.; Sandhu, M.; Sanna, S.; Sayer, A.A.; Scheet, P.; Scott, L.J.; Seedorf, U.; Sharp, S.J.; Shields, B.; Sigurethsson, G.; Sijbrands, E.J.; Silveira, A.; Simpson, L.; Singleton, A.; Smith, N.L.; Sovio, U.; Swift, A.; Syddall, H.; Syvanen, A.C.; Tanaka, T.; Thorand, B.; Tichet, J.; Tonjes, A.; Tuomi, T.; Uitterlinden, A.G.; van Dijk, K.W.; van Hoek, M.; Varma, D.; Visvikis-Siest, S.; Vitart, V.; Vogelzangs, N.; Waeber, G.; Wagner, P.J.; Walley, A.; 
Walters, G.B.; Ward, K.L.; Watkins, H.; Weedon, M.N.; Wild, S.H.; Willemsen, G.; Witteman, J.C.; Yarnell, J.W.; Zeggini, E.; Zelenika, D.; Zethelius, B.; Zhai, G.; Zhao, J.H.; Zillikens, M.C.; Borecki, I.B.; Loos, R.J.; Meneton, P.; Magnusson, P.K.; Nathan, D.M.; Williams, G.H.; Hattersley, A.T.; Silander, K.; Salomaa, V.; Smith, G.D.; Bornstein, S.R.; Schwarz, P.; Spranger, J.; Karpe, F.; Shuldiner, A.R.; Cooper, C.; Dedoussis, G.V.; Serrano-Rios, M.; Morris, A.D.; Lind, L.; Palmer, L.J.; Hu, F.B.; Franks, P.W.; Ebrahim, S.; Marmot, M.; Kao, W.H.; Pankow, J.S.; Sampson, M.J.; Kuusisto, J.; Laakso, M.; Hansen, T.; Pedersen, O.; Pramstaller, P.P.; Wichmann, H.E.; Illig, T.; Rudan, I.; Wright, A.F.; Stumvoll, M.; Campbell, H.; Wilson, J.F.; Bergman, R.N.; Buchanan, T.A.; Collins, F.S.; Mohlke, K.L.; Tuomilehto, J.; Valle, T.T.; Altshuler, D.; Rotter, J.I.; Siscovick, D.S.; Penninx, B.W.; Boomsma, D.I.; Deloukas, P.; Spector, T.D.; Frayling, T.M.; Ferrucci, L.; Kong, A.; Thorsteinsdottir, U.; Stefansson, K.; van Duijn, C. M.; Aulchenko, Y.S.; Cao, A.; Scuteri, A.; Schlessinger, D.; Uda, M.; Ruokonen, A.; Jarvelin, M.R.; Waterworth, D.M.; Vollenweider, P.; Peltonen, L.; Mooser, V.; Abecasis, G.R.; Wareham, N.J.; Sladek, R.; Froguel, P.; Watanabe, R.M.; Meigs, J.B.; Groop, L.; Boehnke, M.; McCarthy, M.I.; Florez, J.C.; Barroso, I. New genetic loci implicated in fasting glucose homeostasis and their impact on type 2 diabetes risk. Nat. Genet. 2010, 42, 105-116.

126. Marz, W.; Nauck, M.; Hoffmann, M.M.; Nagel, D.; Boehm, B.O.; Koenig, W.; Rothenbacher, D.; Winkelmann, B.R. G(-30)A polymorphism in the pancreatic promoter of the glucokinase gene associated with angiographic coronary artery disease and type 2 diabetes mellitus. Circulation 2004, 109, 2844-2849.

127. Weedon, M.N.; Frayling, T.M.; Shields, B.; Knight, B.; Turner, T.; Metcalf, B.S.; Voss, L.; Wilkin, T.J.; McCarthy, A.; Ben-Shlomo, Y.; Davey Smith, G.; Ring, S.; Jones, R.; Golding, J.; Byberg, L.; Mann, V.; Axelsson, T.; Syvanen, A.C.; Leon, D.; Hattersley, A.T. Genetic regulation of birth weight and fasting glucose by a common polymorphism in the islet cell promoter of the glucokinase gene. Diabetes 2005, 54, 576-581.

128. Tam, C.H.; Ma, R.C.; So, W.Y.; Wang, Y.; Lam, V.K.; Germer, S.; Martin, M.; Chan, J.C.; Ng, M.C. Interaction effect of genetic polymorphisms in glucokinase (GCK) and glucokinase regulatory protein (GCKR) on metabolic traits in healthy Chinese adults and adolescents. Diabetes 2009, 58, 765-769.

129. Reiling, E.; van 't Riet, E.; Groenewoud, M.J.; Welschen, L.M.; van Hove, E.C.; Nijpels, G.; Maassen, J.A.; Dekker, J.M.; 't Hart, L.M. Combined effects of single-nucleotide polymorphisms in GCK, GCKR, G6PC2 and MTNR1B on fasting plasma glucose and type 2 diabetes risk. Diabetologia 2009, 52, 1866-1870

130. Stone, L.M.; Kahn, S.E.; Fujimoto, W.Y.; Deeb, S.S.; Porte, D., Jr. A variation at position -30 of the beta-cell glucokinase gene promoter is associated with reduced beta-cell function in middle-aged Japanese-American men. Diabetes 1996, 45, 422-428.

131. Yamada, K.; Yuan, X.; Ishiyama, S.; Ichikawa, F.; Koyama, K.I.; Koyanagi, A.; Koyama, W.; Nonaka, K. Clinical characteristics of Japanese men with glucokinase gene beta-cell promoter variant. Diabetes Care 1997, 20, 1159-1161. 
(C) 2010 by the authors; licensee MDPI, Basel, Switzerland. This article is an Open Access article distributed under the terms and conditions of the Creative Commons Attribution license (http://creativecommons.org/licenses/by/3.0/). 